\title{
Poverty and Public Policy
}

\author{
JAGDISH N. BHAGWATI* \\ Columbia University, New York
}

\section{INTRODUCTION}

The problem of poverty is particularly acute in India. With $14 \%$ of the world's population, we have the misfortune of having almost twice as large a share of the world's poor. Indeed, as I shall presently underline, the question of poverty and its amelioration has been at the center of our concerns from the beginning of our planning efforts almost four decades ago. Little therefore can be said on it that some distinguished Indian economist has not already said. In some ways, therefore, to talk on the design of public policy for poverty to an Indian audience is to carry coal to Newcastle or, as the old saying goes, to teach your grandmother how to suck eggs. Nonetheless, I hope to provide a fresh perspective by putting the problem into an explicit analytical framework that permits alternative policy designs to be sharply defined and contrasted. I also intend to draw on international experience to put our efforts and problems into both historical and comparative perspectives.

\section{ALTERNATIVE POLICY DESIGNS: INDIRECT VERSUS DIRECT ROUTES}

It is possibie, and perhaps even interesting, to speculate whether poverty would increase or diminish if governments followed a regime of laissez faire, letting poverty and all else take a natural course. Few will dispute however the proposition that, except in singular circumstances, public policy should assist in accelerating the amelioration of poverty. ${ }^{l}$ The key question relates rather to the appropriate design of such public policy.

Economics trains us to think of ends and means, of targets and policy instruments. With the amelioration of poverty as the target, the policy instruments designed to achieve that target can be divided into two main classes: (i) the indirect route, i.e., the use of resources to accelerate growth and thereby impact on the incomes and hence the living standards of the poor; and (ii) the direct route, i.e., the public provision of minimum-needs-oriented education, housing, nutritional supplements and health, and transfers to finance private expenditures on these and other components of the living standards of the poor.

The primary distinction between the two approaches is between creating income (and hence consumption) and providing consumption (in kind or through doles). The latter necessarily involves redistribution between different groups unless the financing comes from external resources; the former need have no such component, though complementary policies to bias the creation of income towards the poor, which I discuss below, will often involve redistributive elements. Indeed, within both approaches, the direct and the indirect, we can consider the question of "biasing" or "targeting" the policies in favor of the poor. Thus, the indirect growthoriented route may be supplemented by policies facilitating borrowing and investment by the poor or by redistributive land reform, whereas the direct route may be explicitly targeted towards the poor via means tests or choice of health and nutritional programs that overwhelmingly benefit the poor. ${ }^{2}$

The optimal policy design should generally involve a mix of these two approaches unless the "productivity" of either in achieving the target substantially dominates that of the other. Thus, for instance, if growth will concentrate increased incomes entirely among the non-poor and there

\footnotetext{
*This is the text of the 12th Vikram Sarabhai Memorial Lecture, delivered in Ahmedabad on 28 August 1987. I have profited greatly from conversation with and comments from Surjit Bhalla, Anil Deolalikar, Atul Kohli, Paul Streeten, T. N. Srinivasan, K. Subbarao, K. Sundaram. Raaj Sah, and Suresh Tendulkar. I have taken the opportunity to draw extensively on an earlier treatment of some of these issues in my Michigan State University Distinguished Speakers Series Lecture (Bhagwati, 1985b) on Growth and Poverty, sharpening and extending, however, the analysis presented there and drawing more extensively on Indian experience.
} 
is no upward mobility either, the relevant rate of return to the indirect route is zero. Indeed. if growth can be shown to be immiserizing to the poor, this return would be negative! In this event, the case for exclusive reliance on the direct route becomes overwhelming. with two critical and compelling provisos: first, that it should be shown that the factors, both economic and political, that constrain the effectiveness of the growth process in indirectly reducing poverty do not simultaneously and equally afflict the direct route and prevent it as well from effectively providing benefits to the poor; and second, that the neglect of the growth process. even if its indirect impact on poverty through increased incomes for the poor is negligible or harmful, would impair in the long run the ability of the state to sustain the expenditures required to finance the more productive direct route, especially in an economy with a growing population.

In economic thinking and in economic policy, the pendulum can swing with astonishing regularity. In the 1950 s and 1960 s the growth-based indirect route to attacking poverty was the more fashionable, though the direct route was both recognized and far from neglected. By the 1970 s however, one could hear nothing but a gloomy refrain that the indirect route of growth was ineffective and, worse still, harmful to the poor, and only the direct route in the shape of a Basic Needs strategy was the answer. By the 1980s, the indirect route was restored to grace and seen in a more favorable light, the alarmist assertions of experience with it were being discredited, and the matching difficulties that attend on traveling the direct route were being increasingly appreciated.

Before I proceed to an analysis of the lessons that we have learnt in consequence of this extensive debate, and what they suggest for Indian public policy on poverty, let me turn to two fallacies that have plagued this debate, making it captive to fractious and misplaced ideological confrontations.

\section{(a) Growth: Target or instrument?}

The first fallacy asserts that growth was a rival target to poverty rather than an instrument to ameliorate it. Indeed, in the 1970 s it was commonplace to claim that we had been preoccupied in the 1950s and 1960s with growth, rather than the alleviation of poverty, as our objective. This was the central theme of writings on developmental economics, originating with varying degrees of explicitness from international agencies such as the International Labor Organization (ILO).

Let me confess that this contention may be both true and false. I say this, not in the frolic spirit of my good friend, the philosopher Sidney Morgenbesser. On being asked by one of his radical students during the Cultural Revolution whether he thought that Chairman Mao was right in arguing that a proposition could be both true and false, he instantly replied: I do and I don ${ }^{\circ}$. Rather. I wish to enter the caveat that developing countries form such a mosaic ranging from city states such as Hong Kong to subcontinents such as China, or from democracies such as India to dictatorships such as today's Chile and yesterday's Argentina, that almost everything is valid somewhere and almost nothing is true everywhere. I must confess that the enormity of this problem was brought home to me when I, coming from India with its population of over 750 million. recently visited Barbados with a population of 250,000 . Asked to talk at the Central Bank, I found myself in the Governor's office on the top floor, only to realize that you could practically look out over the island. There was evidently no sensible distinction here between partial- and general-equilibrium analysis! So, to shield myself. I reminded my audience of the famous Mao-Nasser story. On a visit to Peking. Nasser looked unhappy. Concerned. Mao inquired what was wrong. Nasser answered: I am having trouble with my neighbors, the Israelis. How many are there, asked Mao. About two million, Nasser replied. Oh, said Mao, which hotel are they staying at?

I have no doubt that somewhere growth became an objective in itself during the early postwar years. Indeed, it may well have in countries where elites identified GNP, and associated size of the national economy, with respectability and strength in the world economy and polity. But, in influential developmental planning circles, ${ }^{3}$ GNP was simply regarded as an instrumental variable, which would enable one to impact on the ultimate and central objective of reducing poverty.

In fact, in India, which was the focus of intellectual attention during the 1950 s for several reasons, reduction of poverty was explicitly discussed during the late 1950 s and early 1960 s as the object of our planning efforts. In the Planning Commission, where the great Indian planner Pitambar Pant headed the Perspective Planning Division, work was begun at this time on this precise issue. How could we provide "minimum incomes" for meeting the basic needs of all?

The objective being to provide such minimum incomes, or to ameliorate poverty, rapid growth 
was decided upon as the principal instrumentality through which this objective could be implemented. Let me explain why we came to focus on growth as the central weapon in our assault on poverty.

I can speak to the issue, as it happens, from the immediacy of personal experience. For I returned to India during 1961 , to join the Indian Statistical Institute which had a small think tank attached to Pant's Division in the Planning Commission. Having been brought in by Pant to work as his main economist, I turned immediately to the question of strategy for minimum incomes. I assembled such income distribution data as were then available for countries around the world, both functional and personal, to see if anything striking could be inferred about the relationship between the economic and political system and policies and the share of the bottom three or four deciles. You can imagine the quality of these data then, by looking at their quality now almost a quarter of a century later. Nor did we have then anything systematic on income distribution in the Soviet Union. And we had admittedly nothing on China which was an exotic reality, about to make its historical rendezvous with the Cultural Revolution, but already suggesting to the careful scholar that its economic claims were not to be taken at face value.

The scanning of, and reflection on, the income distribution data suggested that there was no dramatic alternative for raising the poor to minimum incomes except to increase the overall size of the pie. The intercountry differences in the share of the bottom deciles, where poverty was manifestly rampant, just did not seem substantial enough to suggest any alternative path. The strategy of rapid growth was therefore decided upon, in consequence of these considerations, as providing the only reliable way of making a sustained, rather than a one-shot, impact on poverty.

I will presently discuss this strategy and its success or failure in some depth. ${ }^{4}$ However, let me return to stress the theme that growth therefore was indisputably conceived to be an instrumental variable, not as an objective per se. It is not surprising therefore that the strange assertions to the contrary by institutions and intellectuals who belatedly turned to questions of poverty in the 1970 s have provoked many of us who were "present at the creation" to take the backward glance and then to turn again to stare coldly and with scorn at these nonsensical claims.

Gilbert Etienne, the well-known sociologistcum-economist, whose heretical and brilliant work on India's Green Revolution I shall soon cite, has exclaimed: "The claim that development strategies in the 1950s and 1960s overemphasized growth and increases of the GNP at the cost of social progress is a surprising one! . . Equally peculiar is the so-called discovery of the problem of poverty" (1982. pp. 194. 195). T. N. Srinivasan and B. S. Minhas, both of whom have worked with great distinction on questions of poverty and who followed me to join Pant's think tank, have been even more critical. I am afraid that I have also been moved to write (1984) in a personal vein: "... . on hearing the claim that poverty had only recently been discovered and elevated as a target of development, I fully expected to find that Chapter One of my 1966 volume on The Economics of Underdeveloped Countries would be titled Growth; behold my surprise when it turned out to be Poverty and Income Distribution!"

\section{(b) Growth and ideology: Pull-up versus trickle-down}

The more egregious fallacy, however, has been for several economists and ideologues to assume that the growth-oriented indirect route must necessarily be a conservative option. The more liberal and radical among them have therefore tended to rush to their computers and their pens each time any evidence suggests that the indirect route may be productive of results, seeking to discount and destroy any such inference.

I have never quite understood this phenomenon. For, the growth strategy was conceived by us at the start of our planned assault on poverty as an activist, interventionist strategy. The government was to be critically involved in raising internal and external savings, in guiding if not allocating investment, in growing faster so that we could bring gainful employment and increased incomes to more of the poor. Whether the policy framework we worked with in India to use the indirect growth-based approach was an appropriate one, and whether therefore this route was efficiently exploited, is a different but critical issue which I will presently address.

Since, therefore, the growth strategy was an activist strategy for impacting on poverty, I have always preferred to call it the pull-up, rather than the trickle-down, strategy. The trickle-down phrase is reminiscent of "benign neglect" and its use in the first Reagan administration to accompany efforts at dismantling elements of the welfare state has imparted yet other conservative connotations to it. The pull-up phrase, on the other hand, correctly conveys a more radical interventionist image and the intellectual context in which it emerged was defined by the ethicallyattractive objective of helping the poor. 
Lest you think that words do not matter, remember your Orwell or the endless battle for the dominant ground between euphemisms and calling a spade a spade. My favorite example from economics is the business schools ${ }^{\circ}$ preferred use of the word "multinationals," nudging your subconscious in the direction of multilateralism and hence evoking the image of a benign institution, and the radicals insistence on calling these international corporations "transnationals," strongly suggesting transgression.

\section{THE INDIRECT, GROWTH-BASED ROUTE: EXPERIENCE AND LESSONS}

Let me then turn to the experience with the indirect, growth-based route.

\section{(a) Immiserizing growth?}

It should be conceded immediately that it is easy enough for economists to construct cases where growth will bypass or will even harm the poor. The pious know that affluence can impoverish one's soul; the economist need not be surprised that it can impoverish one's neighbors too. In fact, in my early scientific work in the late 1950s, I developed a theory of immiserizing growth which established the conditions which yielded a yet stronger possibility: growth would immiserize oneself. ${ }^{5}$ The precise demonstration concerned an economy where increased productivity led to a sufficiently large deterioration in the terms of trade whose adverse effect outweighed the primary gain from growth. Thus, imagine that extension work leads to farmers raising grain production but this, in turn, lowers the grain price so much that the farmers' income falls instead of rising.

As it happens, the paradox that affluence can immiserize oneself is possible to demonstrate even if the affluence comes from transfer pay. ments. Thus international trade theorists have examined conditions under which the recipient of aid may be immiserized rather than enriched, so that a gift horse turns out to be a Trojan horse instead. 6

Such self-immiserizing possibilities naturally require more stringent conditions than the possibility that your affluence causes my misery (even when envy is wholly absent). Thus, consider the scenario where the more affluent farmers adopt the new seeds, grain prices fall and the marginal farmers who have not adopted the new techniques find their stagnant output yielding less income in consequence. In such a situation, the green revolution immiserizes the poor and, the radicals would hope, may usher in the red revolution.

It is not true that we were unaware of such pos. sibilities. that growth could be a disturbingly uneven process. But the key question was: what should this awareness imply for policy? Evidently. you would first need to assess both how such unacceptable outcomes would arise in your specific circumstances and the probability of their arising in practice. Next, the policy set would have to be augmented to include. in addition to growth. further suitable instruments to prevent these unpleasant outcomes. The former requires judgment, based on empirical assessment: the latter, the possibility of finding suitable and feasible policy instruments.

Let me illustrate by reference to the possibility of immiserizing growth that I cited earlier. In the international context, my 1958 model of immiserizing growth was widely considered relevant. including by the distinguished Ragnar Nurkse in his 1959 Wicksell Lectures, because of the generally shared empirical assessment that the export markets of the developing countries were extremely tight, implying that the terms of trade would deteriorate sharply as a consequence of growth in the developing countries. But this assessment, not validated by subsequent analysis and events, did not imply that growth policy had to be abandoned. Rather the growth policy had to be supplemented by an appropriate policy of import substitution, so that we would have what Nurkse called "balanced growth."7

At least in the Indian context, the view taken was that, in the long haul, such adverse possibilities could not be the probable, central result of expanding incomes for any sizable group of the poor, but that rather the process would pull up increasing numbers into gainful work.

While, as I have remarked, the limited and sketchy income distribution data revealed little of any consequence on how to improve this pull-up process, there was awareness that the pull-up effect on poverty would improve, ceteris paribus, if institutional mechanisms such as special credit facilities for the poor were developed, necessary land reforms were implemented, and the access of the scheduled and backward classes (which have disproportionate numbers among the poor) to the opportunities provided by a growing economy were enhanced through preferential schemes. Policy-induced pro-poor bias was thus to be introduced into the growth process, to offset and outweigh any bias in the opposite direction that the market, interacting with inherited political and social forces, may imply. ${ }^{8}$ The concern, therefore, was not with sustained im- 
miserizing outcomes and how to cope with them but rather with the devising of policy instruments to bias the growth process towards greater efficacy of the pull-up effects.

There was also a distinct component, in the strategy. of the direct route, in the public provision of services such as clean water, sanitation, health services and education. The primary thrust of the Indian strategy, however, was to rely on the indirect route. This decision reflected the constraints imposed by the appalling dimensions of India's poverty, and the democratic politics of the country, on our ability to finance a significant reliance instead on the direct route over a sustained period. Noting the former constraint on our planning and fiscal efforts, the famous Polish economist, Michal Kalecki, whose left-wing credentials were never in doubt. had remarked during his visit to India in the early 1960s: "the trouble with India is that there are too few exploiters and too many exploited."

\section{(b) The efficacy of the growth strategy}

India was the focus of interest and attention in the 1950s; distinguished economists and intellectuals descended on it the way they do on China today. Our ideas were influential and came to be shared widely in the efforts by many developing countries to accelerate their growth rates. I have argued elsewhere (1984) that there was a definite optimism during the 1950 s and 1960 s both that growth could be rapid and that it would indeed impact on poverty. But by the early 1970s and later, there were increasing claims that called the efficacy of this strategy into doubt. The criticisms took two different forms: (i) that growth was irrelevant and poverty had increased regardless: a 1977 ILO study (quoted by Etienne, 1982, p. 198) asserted that "The number of rural poor in Asia has increased and in many instances their standard of living has tended to fall. Perhaps, surprisingly, this has occurred irrespective of whether growth has been rapid or slow or agriculture has expanded swiftly or sluggishly"; and (ii) that growth had in fact accentuated poverty: it made the rich richer and the poor poorer; Ghose and Griffin argued in 1979 that "It is not lack of growth but its very occurrence that led to deterioration in the conditions of the rural poor" (quoted by Etienne, 1982, p. 198).

In assessing these claims of increasing immiserization, or mere stagnation in living standards, of the poor, it is necessary to examine not just the evidence and its plausibility, but also whether there was indeed satisfactory growth for the pullup strategy to work where it is alleged to have failed. I am persuaded that the evidence is far less alarming than what it is claimed, that where growth has been rapid it has impacted on poverty, that in the Indian case the growth strategy has produced inadequate results because the policy framework for producing growth has produced inadequate growth in the first place. and hence that the Indian experience suggests lessons in favor of superior growth-producing policies rather than lessons against using the growthbased indirect route to affecting poverty.

\section{(i) International experience}

Let me first stress that countries such as South Korea and Taiwan. which have grown much faster than us in the postwar period to date, have had a substantial impact on their living standards. To see the force of the argument, that India's poor growth performance has affected its prospects for raising living standards, it it useful to understand the force of compound interest. "Had India's GDP grown as rapidly from 1960 to 1980 as South Korea's, it would stand at $\$ 531$ billion today rather than $\$ 150$ billion - surpassing that of the UK. equal to that of France, and more than twice that of China. India's per capita income would have been $\$ 740$ instead of $\$ 260$; even with the benefits of growth inequitably distributed. it is not unreasonable to believe that most of the poor would have been substantially better off." I shall, therefore, return to the question of our policy framework for promoting growth, especially as the moves towards a New Economic Policy were designed to remedy the deficiencies which afflicted that framework.

\section{(ii) Indian experience}

But, even with the relatively dismal growth rate we have had, the evidence is more compelling that some dent has been made on poverty than the doom-and-gloom analysts have often suggested.

The evidence of the National Sample Surveys of consumption is an important source of information here. So are household income and other surveys. Before I sketch what these imply, it is pertinent to remark that many non-economist observers have been skeptical of the reliability of this type of evidence. Distinguished social and economic anthropologists such as M.N. Srinivas. Louis Dumont and Polly Hill have remarked, with varying degrees of candidness, on the quality of Indian data on the subject: and, mind you, these are generally regarded as possibly the best statistics in the developing world. The concepts are inadequate; the implementation yet poorer. Polly Hill (1984, p. 495) has written in frustration and with evident exaggeration that. India's pride. 
"the All-India National Sample survey is perhaps the most remarkable example of wasted statistical effort in the entire world!" Srinivas has complained of the brilliant mathematical statisticians who devise and direct the massive questionnaires to be filled out by field investigators that "This kind of study cannot be left to the hit and run method of an inferior class of investigators who commute from the cities to nearby villages." It is not entirely unreasonable therefore to rely, at least for an alternative view of the matter, on the results from the "naked eye" anthropologicalcum-longitudinal approach to make the required inferences.

Here, I must confess that I have been much impressed by the analysis of Gilbert Etienne (1982), who has argued convincingly from firsthand evidence from extended stays in a number of Indian villages, which he surveyed earlier, that poverty has indeed been impacted on, and that too where agricultural growth has occurred. Etienne's technique is to do what I call "doing in India what you do in China," i.e., disregard the numbers (which in any case are not available in a reliable fashion for China which has only recently opened itself to a measured degree of external and internal scrutiny and independent analysis) and carefully assess what you see. He has gone back over time to several villages that he had looked at intensively, often more than a decade earlier. And he observes, asks, examines, and records: much like Jan Myrdal (1966) in his celebrated Report from Liu Ling but with more anthropological, sociological and economic discipline and less poetry. The results are what we did expect: growth has indeed pushed several of the poor on in life. Doubtless, some poor have been left behind; others have been impoverished even further. But then, as Arthur Lewis has wisely remarked, it is inherent in the developmental process that some see the opportunities and seize them, leaving others behind until they wish to and can follow. Politics and economics can both constrain the capacity of the laggards to follow. Thus, for instance, the green revolution in some instances may well have polarized the distribution of property in the countryside, enriching the farmers with access to credit, fertilizers and irrigation and immiserizing those who did not. But, if Etienne is correct, this has not happened in anything like a significant degree in his cross-section of villages in India. Of course, what Etienne observes may be true only for "his villages." But his unscientific sample is compensated in some degree by the closer scrutiny and care that the scientific surveys evidently do not possess. What do the latter show?

As it happens, even the statistical evidence from these surveys is corroborative, if not wholly conclusive, of the fact that the proportion of the poor below an accepted poverty line has diminished and strongly suggestive of the hypothesis that growth has been a proximate cause of the reduction in poverty.

The recently published estimates of a team headed by B. S. Minhas, who has distinguished himself for pioneering work on estimating poverty along with other noted economists such as Dandekar and Rath (1971), are perhaps the most carefully constructed sets of poverty statistics on the subject. ${ }^{10}$ They utilize new consumer prices for updating the base-year poverty lines and reexamine the recent calculations of the Planning Commission which had suggested a dramatic decrease in the proportion of the poor in the last decade. ${ }^{11}$ It is noteworthy that, while their calculations reduce the degree of improvement estimated by the Planning Commission, they conclude that "The incidence of poverty in 1983 in terms of proportion of people below the poverty line was substantially lower than the corresponding estimates for the 1970s" (Minhas et al., 1987, p. 47), though there is no evidence of a fall in the absolute numbers below the poverty line and, if anything, there may be a small rise in these numbers, reflecting of course the dual pressure and double squeeze of a low growth rate and a rising population.

Again, I must note that Minhas's early work $(1970 ; 1971)$ had drawn attention to the fact that the incidence of poverty goes down in years of good harvests and up in years of bad harvests. This phenomenon is reconfirmed in his recent estimates (Minhas et al., 1987).

My distinguished former student, K. Sundaram of the Delhi School of Economics, who has done notable work with Suresh Tendulkar $(1983 a, 1983 b, 1983 c)$ on the poverty problem, has correctly reminded us (1986) that this relationship requires us to be cautious in inferring any trend in decline of the poverty ratio from the two observations for 1977-78 and 1983 on whose basis we have had to work as far as the estimates based on the NSS Consumer Expenditure Surveys are concerned. ${ }^{12}$ The poverty ratio has fluctuated sharply with agricultural production and the time-series evidence suggests that no trend should be inferred unless more data points are available: the two pleasant observations may simply be reflective of good harvests rather than a better trend.

But this very critique or cautious reminder implies that indeed, as Minhas had noted, there is some evidence for the favorable impact of growth on poverty, at least in the rural sector where $80 \%$ of the poor are to be found. 
In fact, Montek Ahluwalia's classic 1978 paper on rural poverty and agricultural performance had analyzed all-India time series data to underline this precise link. This work has also provoked controversy, with the radical response being provided by Saith (1981) who has drawn the opposite conclusions while working with the same data set. Careful analysis of the two papers by Subodh Mathur (1985), examining both the econometrics and the economics of the issue, reaches the conclusion that "aggregate all-India data support Ahluwalia's contention that agricultural growth reduces poverty."

However, Srinivasan (1985), who has raised several compelling objections to the econometric procedures and inferences in Saith's analysis, also cautions that Ahluwalia's results, which are only confirmed by inclusion of additional data which have become available since 1978 (Ahluwalia, 1985), should not be treated as a decisive test of the pull-up hypothesis. For, the data show that "there was no upward trend in net domestic product of agriculture per head of rural population - there was very little to trickle-down at the all-India level." Discussing also the related work by Bardhan (1982), utilizing some state-level data of still less reliability, Srinivasan has concluded that meaningful tests with more and better longitudinal data than have been available are necessary, by regions or areas differentiated by high and low growth rates, before firm conclusions can be drawn on the issue. But the existing analyses do favor the presumption, for the present, that the effect of growth is to reduce, rather than to bypass or exacerbate, poverty.

Other sources of evidence also suggest that, while poverty remains appalling in its dimensions, it has diminished at least as a proportion of the population. Thus, a careful examination of the estimates of income distribution for India by Bhalla and Vashishtha (1985) concludes that household income surveys (as distinct from NSS-surveys-based estimates discussed above) indicate that if households are ranked by per capita incomes, neither the bottom $20 \%$ nor the bottom $40 \%$ exhibit any significant change in their share of income between 1964-65 and 197576. At the same time, of course, per capita income had increased, so that a constant share would imply a higher absolute level, indicating a decline in poverty. Again, however, these surveys suffer from serious difficulties of comparability, arising from differences in definitions and coverage. Comparable data sets relate only to $1970-71$ and $1975-76$ for the large rural sector: and these indicate favorable conclusions again.
Furthermore, the two recent NCAER longitudinal, nationwide surveys of identical households for 1970-71 and 1981-82 have suggested that. even in the lowest three deciles, there has been a significant rise of households across the poverty line. The proportions who did so are as high as $46 \%, 41 \%$ and $54 \%$ for the lowest, the secondlowest and the next deciles. The results are indeed remarkable, suggesting both that poverty can be impacted and that it has been. Again. however, trends cannot be inferred from two observations; and there are problems, noted by Dr Sundaram (1986, pp. 21-28), with the sample size relating to the poor households and with the fact that there is no way one can infer whether the households changed their fortunes due to increased productivity and income or due to demographic factors. But, when all this is noted, the fact remains that these surveys yield results that do not provide support for the hypothesis of stagnation or immiserization in the living standards of the poor.

\section{(iii) Growth and the New Economic Policy}

If then much of this evidence, with all warts duly registered, suggests some success in assaulting poverty, and this too with only our limited success in enhancing growth, the key question rather becomes: why has our growth been so disappointing?

Our record of growth is admittedly one of acceleration over the pre-Independence period and compares well with that of countries in the 19 th century. But we need to remember that this is the case with most of the developing countries in the postwar period and that, compared to them, we appear as unfortunate laggards.

In fact, most of us were pleasantly surprised, despite our optimism, at the remarkable growth rates turned up by the developing countries after World War II. The reasons are probably selfevident. Whereas the pre-Industrial Revolution growth rates were dependent largely on capital accumulation, they increased in the postIndustrial Revolution period because of unprecedented technical change. The developing countries, by contrast, could combine increasing rates of external and internal savings with influx of off-the-shelf technology and thus grow very rapidly. Many did.

The productivity of the increased rates of investment has, however, varied, depending on the policy framework within which the economy operated. There is sufficient evidence, in my judgment, that our policy framework degenerated by the early 1960 s on critical fronts, confining us to a trend growth rate of roughly $3.5 \%$ per annum or about $1.5 \%$ per capita growth rate annually. ${ }^{13}$ 
Despite an almost three-quarters increase in our fixed investment rate over the period $1950-$ 84. we had little improvement in the growth rate. If we break the period into 1951 to 1965 (coinciding roughly with the Nehru and pre-wheatrevolution era) and 1968 to 1984 (omitting the two severe drought years of $1965-66$ and 1966$67)$. the trend growth rate is $3.88 \%$ in the former period and $3.75 \%$ in the latter, there being no statistically significant difference between the two rates (Bhagwati and Srinivasan. 1984). The decadal average growth rate of the $1950 \mathrm{~s}$ $(3.59 \%), 1960 \mathrm{~s}(3.13 \%)$ and $1970 \mathrm{~s}(3.62 \%)$ are also similar. Evidently, we got our policy framework wrong.

Economic analysis is often unable to detect unique causes of the phenomena being explained. In this instance as well, the contributory factors are by no means the only two I shall cite; but they are certainly among the most important. ${ }^{1+}$ The first relates to the excessive and explosive growth of controls over industry and foreign trade until the most recent changes; the second concerns the failure to exploit the advantage of foreign trade.

The growth of controls turned our governmental intervention, so necessary in a developing country, into a counterproductive one. A government of "don'ts" will stifle initiative; it will also divert entrepreneurial energies into a number of wasteful rent-seeking and other directly unproductive profit-seeking (DUP) activities. By contrast, a government of "do's," such as the one which the successful countries of the Far East have had, is likely to harness its people's energies more productively, even if its prescriptions are mistaken from time to time. It is an increasing appreciation of these questions, and the sense that our Kafkaesque maze of controls could not possibly be sensible, that led me and others during the late $1960 \mathrm{~s}$, and recently many others still, to call for a progressive dismantling of this monstrous constraint on our economic efforts. I may remind you in particular that I. G. Patel, who oversaw our economic policy with distinction for much of this period, recently took the occasion of the Kingsley Martin Memorial Lecture to join us in our corner and ask dramatically for a "bonfire" of the industrial licensing system. ${ }^{15}$

As for the inability we have exhibited in exploiting the gains from trade in a world economy that grew at unprecedented rates in the 1950s and 1960 s and which still continues to absorb rapidly expanding exports from the developing countries, the explanation lies in what social scientists call the "self-fulfilling prophecy." Despite all evidence to the contrary, our planning and policy framework was continually based on what eco- nomists call "export pessimism." The failure to use the exchange rate actively to encourage exports as in other countries, the inflexibilities (introduced by the pervasive controls) which must handicap the ability to penetrate and hold fiercely competitive foreign markets, the protection and hence attractiveness of the home market: these policies produced a dismal export performance, while other successful countries expanded their exports rapidly and gained in economic growth greatly. ${ }^{6}$ How dismal our export performance has been can. in fact, be understood readily by noting that our share in world exports was only $0.41 \%$ by 1981 , having fallen almost continually since 1948 when it was $2.4 \%$. This certainly affected even our industrial sector's growth. For, other countries which began with a much smaller industrial base are not only exporting more manufactures than India but, what is more striking, catching up with India in the absolute size of their manufacturing sector. The size of Korea's manufacturing sector, for example, was less than $25 \%$ of India's in 1970 (measured as value-added). By 1981, it was already up to $60 \%$. Korea's manufactured exports, negligible in 1962, amounted by 1980 to nearly four times those of India's! ${ }^{17}$ Simply put. we missed the bus.

I agree that we could not have grown as fast as the Far Eastern economies, the Gang of Four (as I christened them with success many years ago) or the Four Tigers, because we had a much larger agricultural base. Our agriculture, I agree again with Professors Dantwala (1970) and Srinivasan (1982) among others, grew about as fast as could be expected and charges of its neglect are seriously exaggerated. ${ }^{18}$ But to infer from this that India could not have grown much faster than it did is to forget again the force of compound arithmetic: non-agricultural growth, in an economy geared to rapidly expanding trade and nonagricultural production, would have provided a growing impetus to the economy, steadily overwhelming the agricultural sector's importance in both value-added and employment.

\section{(iv) Growth patterns}

How would such a shift to an export-promoting strategy have affected the pull-up process of creating more gainful employment? The proponents of the import-substituting strategy, on which we continued to place total reliance instead, have suggested that the export-promoting strategy would have been less productive of employment, even if it may have produced more efficiency. Quite aside from the fact that the empirical evidence suggests that the export promoting strategy implies in practice faster 
growth and impact on poverty, there is yet further evidence that, even in the short run, export promotion has been associated with more labor-intensive investment and production. I refer here to the important findings of Professor Anne Krueger (1983) and her associates in her major three-volume study of this subject. The export-promoting strategy has not merely led to more rapid income growth but also produced greater increase in demand for labor. ceteris paribus. A major reason is the laborintensiveness of export industries in the exportstrategy-led countries.

\section{(v) Growth and political economy constraints}

Why did these serious deficiencies afflict our planning efforts? The question belongs to the new field of political economy. In particular, my theory of the causes and consequences of proliferation controls is that initially they were the product of ideas and ideology, then they led to the growth of interests, and now as the ideas and ideology have shifted these interests pose a critical obstacle to the desired shift of strategy.

At the outset. few of us realized that controls could proliferate in the way they did. In the early 1950 s industrial controls appeared to be sensible instruments, to allocate resources in directions worked out in the Planning Commission. Industrial licensing would eliminate excess capacity by regulating entry; scarce resources would be channeled in optimal directions. Pretty soon, however, the promotional agencies such as the DGTD had largely turned into restrictive and regulatory agencies instead; and in no time we were operating in a regime where one could not even exceed licensed capacity or diversify production lines in any way without retribution. A straitjacket had evolved from what seemed like a reasonable economic approach to investment allocation.

This economic regime spawned its own interests. The rentier society it yielded, with entrepreneurs enjoying squatters rights, created a business class that wanted liberalization in the sense of less hassle, not genuine competition. The bureaucrats, however idealistic at the outset, could not but have noticed that this regime gave them the enormous power that the ability to confer rents generates. The politics of corruption also followed as politicians became addicted to the use of licensing to generate illegal funds for elections, and then for themselves. The iron triangle of businessmen, bureaucrats and politicians was born around the regime that economists and likeminded ideologues had unwittingly espoused.

As ideas have now changed, through the pro- cess of "learning by undoing," these interests now stand in the way of rapid, if any, change. While the erstwhile partnership of the Prime Minister Rajiv Gandhi and the then Finance Minister Vishwanath Pratap Singh was apparently determined to take the necessary steps to start on a program of removing the straitjacket on the Indian economy, and their leadership was evidently of great importance in defining sharply a promise of new policies, the hesitations and obstacles from both the intellectuals of the older vintage and the interests of the iron triangle have been manifest, raising acutely the question whether the early momentum for change can be politically maintained. ${ }^{19}$

\section{(vi) Pro-poor-bias policies and political economy constraints}

I am afraid that the pro-poor-bias policies have equally run into difficulties, arising from unequal asset distribution and hence unequal political power at the grassroots level. The degree of success of policies aimed at improving the pull-up effects of the growth process is evidently a function of the extent to which "countervailing power" is available to the poor through the presence of social action groups and politically viable proposition parties. ${ }^{-10}$

Here again, however, I should like to emphasize that, in the longer run, substantial growth itself is a factor generating the necessary countervailing power through the marketplace, by raising the demand for labor and increasing its opportunity cost. I hypothesize that the relative success of tenancy reform in Gujerat must have also some relationship to the fact that many of those who "lost their lands" to it had little incentive to fight and evade the reform in view of the fact that they already had shifted to urban careers and the transaction costs of the efforts at evasion were in consequence just too high.

\section{(vii) Radical restructuring: Why not?}

Let me add some remarks about radical restructuring of the asset structure and transition to fuller socialism do la China and Cuba as possible alternatives to our policies for creating a sustained impact on poverty.

I am afraid that the skepticism that marked the enthusiasm for the Chinese experiment appears to have only been reinforced by later developments. In the 1950 s it was often thought that, if only a Chinese revolution could be ushered into the developing countries, its triumphs in eliminating poverty could be replicated. The skepticism lingered because systematic scrutiny of the Chinese claims was not possible; and one legitimately wondered whether absolute poverty had 
truly been reduced and also whether growth could be sustained within the new framework. raising questions about the sustainability of the immediate impact on poverty. Now. after the window has steadily opened wider in the aftermath of the Cultural Revolution and the failures of the Great Leap Forward, we are not sure at all.

We know now that the barefoot doctors generally wore shoes: that their professional competence occasionally exceeded only marginally that of the average grandmother: and that doctors have dragged their feet almost as successfully as elsewhere when assigned to go to the country-side, indeed to the point where Liushao-chi's major crimes were declared by the Red Guards and official pronouncements to include sabotage of the campaign to carry doctors to the rural areas. We are further told that the Chinese concept of equality was intra-commune. not between communes: the rich communes did not generally share their affluence with the destitute ones. And we are now told by the new regime that more than $10 \%$ of the Chinese population may be below a rather austere poverty line.

These tantalizing glimpses into China's assault on poverty will almost certainly not be allowed to develop into a fuller picture as in other developing countries, since careful and unfettered scholarly scrutiny is unlikely to be possible in the degree necessary. I am afraid therefore that we shall have to reconcile ourselves to the uncomfortable situation where we do not know for certain the extent to which China's ex ante egalitarian methods failed ex post, and whether the failures were due to discordance between their announced and their true objectives or rather due to the limitations of the methods used to achieve the announced objectives.

\section{(viii) Equitable asset distribution}

On the other hand, the proposition that a more equitable distribution of assets at the start of the growth process will generally imply that the new incomes will, in turn, be distributed better is of course quite plausible. In the end, over a longer period, the forces that generate inequality will tend to unequalize the outcomes. But over a generation or two, the net outcomes would be more equal than if we were to start with unequal distribution of assets. The experience of South Korea and Taiwan, where Japanese occupation is largely credited with having brought about the initial asset-ownership equalization, underlines this near-truism well. Also the experience in India, where several micro-level studies have shown the link between asset-ownership and new-income distribution to be a significant factor in a fair number of cases, only underlines the wisdom of supplementing the growth-oriented approach with policy measures that counter this bias (Tendulkar. 1983).

A policy of "redistribution with growth." where the redistribution of assets precedes the growth that is designed to impact on poverty, has therefore been advocated by several disting. uished economists. "I If such redistribution can be undertaken politically, and its implementation is not disruptive economically (as was the case with Soviet collectivization). ${ }^{22}$ we can only rejoice.

\section{(ix) From income to consumption}

We also face, even when incomes have reached the poor, a final set of dilemmas.

First, as the sociologists of poverty have long known, the poor may spend their incomes on frills rather than on food. As the Japanese proverb goes: each worm to his taste: some prefer nettles. Perhaps you have heard of the seamen's folklore which recounts the story of the sailor who inherited a fortune, spent a third on women, a third on gin, and "frittered away" the rest.

In fact, there is now considerable econometric evidence, reviewed splendidly by Behrman and Deolalikar (1987c), that supports the common sense view that increases in income do not automatically result in nutritional improvement even for very poor and malnourished populations. ${ }^{23}$ Their high income elasticities of expenditure on food reflect a strong demand for the nonnutritive attributes of food (such as taste, aroma. status and variety). suggesting strongly that income generation will not automatically translate into better nutrition.

For those of us who feel that certain basic needs ought to be satisfied, this tragic assertion of what economists have come to call rather extravagantly "consumer sovereignty" leaves us confronting a familiar moral-philosophical issue. Should we actively intervene so that the poor are seduced into better fulfillment of what we regard as their basic needs? I do. In fact, I see great virtue in quasi-paternalistic moves to induce, by supply and taste-shifting policy measures, more nutrient food intake, greater use of clean water, among other things, by the poor. In thus compromising the principle of unimpeded and uninfluenced choice, for the poor and not for others. evidently I adopt the moral-philosophical position that 1 do not care if the rich are malnourished from feeding on too many cakes but do if the poor are malnourished from buying too little bread, when their incomes can buy them both proper nourishment if only they were to 
choose to do so. In this, I am in the ethical company of Sofya (Sonia) Marmeladova in Dostoevsky's Crime and Punishment who, in turning to prostitution to support her destitute mother, sacrifices virtue for a greater good.

\section{(x) Whose consumption: Gender et al.}

Next, in addition to the first, is the other dilemma: that even when households have consumed what is desirable and adequate on a per capita basis, its distribution within the household may be such as to deprive the weaker members, such as females, of an adequate access to the consumption basket. In the 1970 s I was somewhat isolated (Bhagwati, 1973) as an economist in being seriously interested in the sex-bias that was visible in the statistics on educational enrollments, literacy, infant mortality and nutritional levels, much of the evidence coming from anthropological findings and other surveys. ${ }^{2+}$

Now, almost a decade later, many others have followed and are actively analyzing the problem so that we now know more, though not enough. about this key component of our problems in improving living standards. Among the important findings, I should note the Behrman and Deolali$\operatorname{kar}(1987 \mathrm{~b})$ result that the intra-household discrimination may not merely be in the form of lower quantities of food/nutrients allocated to weaker members such as females, but may also occur in the form of greater fluctuations in the quantities allocated to them in response to adverse food price changes.

Additional policy instruments are evidently necessary to offset this bias if the elimination of poverty is to occur more rapidly and equitably. The task here is clearly harder than simply generating more income; and progress in the matter may have to depend on the spread of education in the first place.

\section{THE DIRECT ROUTE: EXPERIENCE AND LESSONS}

What then have we learnt about the direct route, its efficacy and productivity?

It is important to enter the caveat immediately that the key issue is not whether this route produces results but rather its productivity relative to that of the indirect route. It would be astonishing indeed if greater public health expenditures or direct income transfers did not produce some improvement in the living standards of the poor, even though it is not beyond the ingenuity of economists to produce paradoxes of immiserization in this area as well. ${ }^{25}$

\section{(a) Eating your cake and having it too}

At the outset, it is worth noting that there are significant externalities for growth itself from expenditures on publicly provided services. Many of us have been surprised, though pleasantly this time, by the realization that we had exaggerated our early fears about the trade-off between "consumption" expenditures (such as financing education and health) and investment expenditures aimed at growth and hence ultimate impact on poverty. It is difficult today to appreciate the widespread notion in the 1950 s that primary education was simply a "natural right," whose implementation reflected the availability of resources. That it was possibly an important means for raising productivity and hence growth and therefore reducing poverty, and that it could therefore be justified also on consequentialist ethics, was a later phenomenon. This holds equally for health expenditures which were viewed with inhibited enthusiasm also for fear that they would exacerbate population growth. Only later were they considered to have a possible productivityenchancing effect on populations that could otherwise be working at impaired efficiency or even to lead to a lowering of the birth rates if, by reducing infant mortality and increasing survival rates, they enabled parents to produce fewer babies to wind up with their target family size in a steady state.

Much of the currently available indirect or "macro" evidence on this issue has recently been ably reviewed by Bela Balassa (1983). Thus, for instance, Correa (1970) has argued that improvements in health (proxied by reductions in death rates and in work days lost) and nutrition (measured as increases in calorie intake) added 0.12 to 0.93 percentage points, and improvements in education (measured as the average level of education of the working force) added 0.05 to 0.53 percentage points to the rate of economic growth in nine Latin American countries during 1950-62. Again, Norman Hicks (1980) has estimated that a 10-year increase in life expectancy raises per capita GDP growth rates by 1.1 percentage points and a 10 percentage point increase in literacy rates by 0.3 percentage points.

But, of course, health and education expenditures affect growth and the other way around. Simple regressions therefore can be misleading and simultaneous estimation is necessary. David Wheeler (1980) and Robin Marris (1982) have done precisely this, the former for $\mathbf{8 8}$ developing countries for $1960-73$ and $1970-73$ as well as pooled data for the whole period, the latter for 37 middle-income and 29 low-income countries for 
1965-73 and for 1973-78. Wheeler's findings indicate significant impact on growth rates from increases in calorie intake and in literacy rates. Marris's study found that primary education enrollments had a favorable effect on growth rates of per capita income whereas increased life expectancy and family planning helped through reductions in the rate of growth of population (Balassa, 1983, pp. 10-11).

But more compelling is the direct, "micro" evidence linking health, in particular, to productivity. I should note here the recent econometric work on Indian data by Deolalikar (1988), though there is by now a substantial literature that analyzes the issue both theoretically and econometrically.

More is known now, therefore, to wean us away from the fear that such educational and health expenditures are necessarily at the expense of growth. What is equally pleasurable is the fact that many of these arguments apply with yet greater force when the expenditures are addressed to the poorer segments of the population. The case for undertaking more such expenditures, with focus on the poor, consistent with being engrossed in the growth strategy, is therefore now seen to be stronger than ever before. $^{26}$ I think we have learnt that, within reasonable margins, we may then be able to eat our cake and have it too. Social expenditures could improve the welfare of the poor directly and also indirectly through growth which in turn would impact on poverty. But beyond these margins, the trade-off remains an issue.

\section{(b) Political economy constraints}

At the same time, as Lakdawala (1986) has recently emphasized, income expansion itself can be a precondition for utilization of the publiclyprovided services. For, such income can "take care of the incidental expenditure incurred in using these facilities" (p. 392). ${ }^{27}$

In fact, this observation underlines the fact that the political economy factors that have prompted and also constrained the measures to offset the anti-poor biases in the growth-based indirect route are unlikely to disappear when we turn to the direct route. Thus, nutrition programs through schools go to those who attend schools and therefore will not seriously impact on the poor whose children do not get to school: a phenomenon noted by researchers in the 1970s already. The successful impartation of a pro-poor bias in direct expenditures for living standards improvement is, in our experience, likely therefore to face difficulties somewhat parallel to those faced in the pursuit of the pro-poor-bias policies in the indirect. growth-based route. ${ }^{2 *}$ In the 1970s, when the indirect growth-based route's productivity was being significantly understated in the international discussions, as I have already argued, the productivity of the direct route was being overstated by ignoring the political-economy constraints that afflict the latter as well.

\section{Overstated productivity?}

The productivity of the direct route may have been overstated also through an overly-optimistic inference from two allegedly outstanding success stories widely cited in this literature: Sri Lanka and Cost Rica.

As it happens, however, a brilliant analysis of Sri Lanka by Bhalla (1985a, 1985b) and then by Bhalla and Glewwe $(1985.1986)$ has called this story into question. Apparently Sri Lanka's claim to attention consisted in substantial direct expenditures and also splendid performance on indices such as literacy, life expectancy and infant mortality rates which were then assumed to be a result of these direct expenditures. But these indicators were already remarkably high by 1948 itself: a fact that was not allowed for in the argumentation which relied astonishingly on single-time-period cross-country comparisons. ${ }^{29}$ When changes in these indices are considered for 1960-78, it turns out that Sri Lanka's perform. ance on these criteria shrinks into mediocrity. Of six indicators analyzed, for only two - life expectancy and the death rate - does Sri Lanka do better than average; and, if a strict statistical test is used, only the death rate survives to fit this bill.

With this reversal of conclusions based on changes in, rather than on levels of, the performance indicator, ${ }^{30}$ the question arises whether the low performance of Sri Lanka in this recent postwar period reflects low growth rates, reinforcing exactly the opposite conclusion to what is presumably being contended! As it happens, estimates of Sri Lanka's per capita income growth show that, during 1960-78, Sri Lanka had a negative annual growth rate of $-1.2 \%$ along with only five other countries including Burundi. Benin and Angola! Can it be that the diversion of expenditures away from growth to ("social") direct expenditures affected growth adversely and hence impacted on the poor more than the direct expenditures helped them? Or were economic policies so bad that growth was affected adversely and impacted on the poor, and increased direct expenditures had to be undertaken to offset the adversity for the poor? In short, the mediocrity of Sri Lanka's recent performance on the living standards of the poor may be explain- 
able by hypotheses that only sustain the advisability of assigning primacy to the growth-oriented route to ameliorating poverty.

Of course we can still speculate as to what made Sri Lanka in 1948 such an impressive performer on living standards. Was it high growth rates or high social expenditures? Was the productivity of the latter high due to specific, manageable problems such as malaria which could be eradicated relatively easily with public-health anti-malaria programs and therefore has little value in inferring general prescriptions? Only detailed historical analysis, carefully sifting among different hypotheses, can throw light on the issue at hand. In the meantime, the ready overoptimism that the early writings on Sri Lanka's postwar experience reflected and spread must be suspended.

\section{CONCLUDING OBSERVATIONS}

In the end, therefore, I see no quick fix to our immense poverty problem. We can debate whether resources can be moved further at the margin from the indirect. growth-based route to the direct, minimum needs route. But the most important lesson seems to be that. within each route, we can and must get significantly more returns than we have to date.

Within the indirect route, the New Economic Policy initiatives point in the right direction and, if successfully brought to fruition, promise a significantly greater impact on poverty in the next two decades than we have had with our inappropriate policy framework and dismal economic performance. Within the direct route, there is continual improvement being sought of course and an economist has little expertise to offer. Efforts such as integrated, block-level development programs and the introduction of the village community heaith workers et al. are the fruit of ongoing processes of learning by experience: they ought to yield results over time. ${ }^{31}$

I have two further thoughts to conclude my lecture. That our low growth rate seems to have reduced our poverty ratio but left the absolute numbers of the poor at an appalling level of over 300 million. suggests not merely that we must pursue doggedly the New Economic Policy initiatives. It also underlines the critical role of a successful population control program. Derailed by the draconian measures during the Emergency, this program needs to be pushed vigorously if the fruits of growth are not to be squandered on supporting increasing numbers rather than improving the well-being of fewer people.

At the same time, the political economy constraints on both the indirect and direct routes ability to reach the poor more effectively. despite governmental attempts at offsetting these biases, underline the overreaching importance of the role of voluntary agencies and social action groups. The ex ante intention of the enlightened sectors of our governments will not effectively translate in many instances into ex post outcomes in our assault on poverty without the active association of such agencies.

These social action groups do not merely aid the poor directly but also by acting as watchdogs that assist the poor in securing effective access to the programs designed by the government for their benefit. This is the lesson, for example, of the Legal Aid Programme in India where the coopting of such agencies has turned out to be an essential ingredient in making the program more productive.

Indeed, private and public altruism have, therefore. a critically complementary role in creating a shared success in the assault on poverty.

\section{NOTES}

1. Such a singular circumstance could be a Myrdaltype "soft" state or a predatory state; the former would preclude effective action whereas the latter would guarantee malign intervention.

2. There are two main "anti-poverty" programs in India, the Integrated Rural Development Programme (IRDP) and the National Rural Employment Programme (NREP). Both of these are targeted at the poor and would classify as part of the indirect, growthbased strategy in my typology since they are intended to bias the creation of assets and income in favor of the poor. Thus, for instance, the IRDP aims at targeting the poor in the growth process by providing them with opportunities, in terms of transfer of assets, training etc., for income expansion. The NREP. on the other hand, creates rural employment to build assets such as roads and therefore can be seen as an attempt at biasing the income-expansion process in favor of the poor by promoting labor-intensive technologies and activities and also, insofar as the assets in turn create income differentially in favor of the poor, via the resulting capital formation as well. In practice, however, the asset formation, such as road building. may be negligible as when the new roads are immediately washed away, reducing therefore the result in this instance to what it would have been under a transfer payment to the poor as in my direct route. There is, therefore, an extensive 
debate in India whether the operation of the IRDP and NREP programs, while intended as part of the propoor-bias indirect (growth) strategy. are not de facto reducing to the pro-poor-bias direct (transfer) strategy. On this issue. see the interesting articles by Rath (1985) and Sundaram and Tendulkar (1985). I am indebted to Sundaram and Tendulkar for drawing my attention to these questions.

3. Here, I refer to economists such as myself, B. S. Minhas. K. N. Raj and T. N. Srinivasan who were actively involved in planning efforts within institutions such as the Indian Planning Commission, and to planners such as Pitambar Pant. That some of the purely academic development economists were preoccupied with models that addressed growth per se, and would discover poverty as an explicit target and as an issue for analysis many years later, is an observation compatible with the fact that some of us at the center of planning efforts were not so afflicted.

4. I have dealt with the growth strategy at much greater length in my 7th Sir Purshotam Thakurdas Memorial Lecture (Bhagwati, 1987) which should therefore be read as a companion piece to the present lecture.

5. See Bhagwati (1958). The model used was developed earlier by Johnson (1955) to examine the interactions between growth and trade.

6. Such a paradox may be described as implying an Invisible Shakedown (by the donor). See Bhagwati, Brecher and Hatta (1984).

7. In economic jargon, one has a case for an optimum tariff here. Again, later developments in the theory of immiserizing growth show how it can be ruled out if optimum tariffs are imposed. See Bhagwati $(1968 ; 1986 c)$

8. On Indian policies with regard to biasing credit facilities towards the poor, see Tendulkar's (1983) excellent review.

9. This graphic comparison and scenario come from Myron Weiner's (1986) interesting analysis of the political economy of India's appallingly slow growth rate, with much of which I am in agreement. I should stress that, in using South Korea's growth rate to make this comparison compelling, I do not mean to imply that we could have improved our economic performance quite that much!

\section{Minhas, Jain, Kansal and Saluja (1987).}

11. These estimates continue to use the definition of poverty line adopted by the Indian Planning Commission in the mid-1970s.

12. These surveys are available on an annual basis almost continually up to $1973-74$ but only for 1977-78 and 1983 thereafter.
13. Many statistical tests have cast continuing doubt on the question whether our growth rate has finally accelerated in the last decade. All plausible ways of splitting the period 1950 to 1984 turn up conclusions that suggest unchanged trends. See Bhagwati and Srinivasan (1984) and Joshi and Little (1986), among other analyses of these trends.

14. I have discussed these and other explanations at greater length in the 7th Sir Purshotam Thakurdas Memorial Lecture (Bhagwati, 1987).

15. See Patel (1986). He is fully aware. of course, that the elimination of this system is a goal whereas the process will require extremely careful management. Whether the growth of interests. supportive of this system. over its existence in the past three decades will pose insuperable obstacles to its removal is an issue in political economy that I discuss at greater length elsewhere: Bhagwati (1986a, 1986d, 1987).

16. This is not the place to report yet again on the numerous research projects that showed in the 1960s and 1970 s how export pessimism had been unjustifited but had led to dismal export. and in turn to dismal eco. nomic, performance in many countries. Useful reviews of this research are not available; see Bhagwati (1986b) and Balassa (1986).

\section{See Bhagwati and Srinivasan (1984).}

18. Ibid.

19. That the interests followed the ideology and now constrain a shift in the ideology is a thesis different from that of Professor Pranab Bardhan (19S5) who differs from me both in starting from the interests and also in relating them wholly to public sector losses and therewith to slow growth. I have discussed the role of public sector savings in India's slow growth at some length in the Sir P.T. Memorial Lecture, again emphasizing the early role of ideas and the subsequent role of interests.

20. Evidence on the relationship of party politics to the successful implementation of anti-poverty programs have been ably analyzed recently by the Princeton political scientist Atul Kohli (1987).

21. See Adleman and Morris (1973) and Chenery et al. (1974). In this generic class of strategies. I would also include an altogether different kind of proposal that I made for Indian planners to consider in 1973 in the Lal Bahadur Shastri lectures. I argued for a fractional nationalization of land in each village (or similar unit), which could be set apart to form a Chinese-style commune. Those destitute who wished to follow the slow and protracted route offered by the Indian strategy of predominantly relying on growth to impact on poverty, would take their chances there; but those who wished to gain employment and some income right away would have immediate access to the commune $\dot{a}$ la China. The combination of both strategies, and access to either by choice, would mean that the destitute 
were not forced into the Indian option of freedom but slow poverty alleviation or into the Chinese option of freedom through forced removal to the communes but more rapid and, one hoped, sustained removal of abject poverty

22. These are hazards that do not seem to have afflicted China since the elimination of the kulaks seems to have occurred principally during the long civil war itself. See Desai (1975).

23. For a fine review of India's experience with interventions to fill nutritional gaps at the household level. see Subbarao (1987).

24. See, for instance, Sundaram (1973). Rosenzweig and Schultz (1982), Sen (1984) and Kakwani (1986).

25. E.g., a successful anti-malaria program may increase population pressure, reduce real wages, affect nutritional intake of the poor and disproportionately depress their living standards inclusive of their own life expectancy. Economists who like immiserization paradoxes on the indirect route should look out for them on the direct route as well.

26. On the other hand, the difficulties of directing the expenditures on primary education and health effectively to the poorer classes when the elites control the political system need to be recalled again. Questions such as the relative priority attached to primary and higher education in state spending and its relationship to the class nature of the state have been discussed at length by economists such as Samuel Bowles and myself. See the extended analysis in my "Education, Class Structure and Income Equality" (1973a).

27. This observation is also corroborated by the careful study of the regional variations in the impact of India's Anti-Poverty programs by Subbarao (1985).

28. This is evident also from the important in-depth analysis of the working of the NREP program in Gujarat State by Indira Hirway (1986a, 1986b).

29. This argument was advanced by Isenman (1980) and Sen (1981), among others.

30. The lack of availability of data on changes in levels of direct expenditures prevents us from drawing more compelling inferences here, as noted by Bhalla (1985) himself. Also, such evidence as is available on changes in educational expenditures does not help the critics of Bhalla either: See Bhalla and Glewwe (1986) and the later animated comments by Pyatt (1987) and Isenman (1987) and the riposte by Glewwe and Bhalla (1987).

31. See the excellent review of these problems and their possible solutions in Lakdawala (1985), based on his tenure as Deputy Chairman of the Planning Commission.

\section{REFERENCES}

Adelman, Irma, and Cynthia Taft Morris, Economic Growth and Social Equity in Developing Countries (Stanford, CA: Stanford University Press, 1973).

Ahluwalia, Montek S., "Inequality, poverty and development." Journal of Development Economics, Vol. 3 (1976).

Ahluwalia, Montek S., "Rural poverty and agricultural performance in India," Journal of Development Studies, Vol. It (1978).

Ahluwalia, Montek S., "Rural poverty, agricultural production and prices: A re-examination." in John Mellor and Gunvant Desai (Eds.). Agricultural Change and Rural Poverty: Variations on a Theme by Dharam Narain (Baltimore, MD: Johns Hopkins University Press, 1985).

Ahluwalia, Montek S., Nicholas G. Carter, and Hollis B. Chenery, "Growth and poverty in developing countries," Journal of Development Economics, Vol. 6 (1979).

Balassa, Bela, "Public finance and social policy Explanation of trends and developments: The case of developing countries," DRDERS, World Bank Report No. DRD 65 (Washington, DC: World Bank, November 1983).

Balassa, Bela, "The importance of trade for developing countries," Paper presented to the IBRD-TDRI Conference on "The MTN and Developing Country Interests," Bangkok, Thailand (Oct-Nov 1986).

Bardhan, Pranab, "Poverty and the 'trickle-down' in rural India: A quantitative analysis," Mimeo (Berkeley, CA: University of California, 1982)

Bardhan, Pranab, The Political Economy of Development in India (Oxford: Basil Blackwell, 1986).

Behrman, Jere R., and Anil B. Deolalikar, "Health and nutrition," in Hollis B. Chenery and T. N. Srinivasan (Eds.), Handbook on Economic Development, Vol. I (Amsterdam: North-Holland Publishing Co., 1987a), Chap. 15

Behrman, Jere R., and Anil B. Deolalikar, "How do food prices affect individual nutritional and health status? A latent variable fixed-effects analysis," Mimeo (1987b).

Behrman, Jere R., and Anil B. Deolalikar, "Will developing country nutrition improve with income? A case study for rural South India," Journal of Political Economy, Vol. 95, No. 3 (1987c).

Bhagwati, Jagdish N., "Immiserizing growth: A geometrical note," Review of Economic Studies (June 1958); reprinted in Robert Feenstra (Ed.), Essays in International Economic Theory. Vol. 1, The Theory of Commercial Policy (Cambridge, MA: MIT Press, 1983).

Bhagwati, Jagdish N., The Economics of Developing Countries, World University Library Series (London: Weidenfeld and Nicolson, 1966).

Bhagwati, Jagdish N., "Distortions and immiserizing growth: A generalization," Review of Economic Studies, Vol. 35, No. 104 (October 1968). 
Bhagwati, Jagdish N., "Education, class structure and income inequality." World Development. Vol. I. No. 5 (1973a).

Bhagwati, Jagdish N.. India in the International Economy, Lal Bahadur Shastri Lectures (Hyderabad. India, 1973b): reprinted in J. N. Bhagwati, Essays in Development Economics, Vol. 1, Wealth and Poverty (Oxford: Basil Blackwell, 1985), Chap. 2.

Bhagwati, Jagdish N., "Development economics: What have we learned?" Asian Development Review, Vol. 2. No. $1(198+)$.

Bhagwati, Jagdish N., "Gandhi's break with the past: Is India's economic miracle at hand?" The New York Times (9 June 1985a).

Bhagwati, Jagdish N., Growth and poverty, Michigan State University Centre for Advanced Study of International Development, Occasional Paper No. 5 (East Lansing: MI: Michigan State University. 1985b).

Bhagwati, Jagdish N.. "Controls must be liberalized: An interview with Jagdish Bhagwati," Frontline (May-June 1986a).

Bhagwati, Jagdish N., "Export-promoting trade strategy: Issues and evidence," World Bank Policy Issues Papcr, VPERS (Washington, DC: World Bank. 1986b): forthcoming in World Bank Research Observer (1988).

Bhagwati, Jagdish N.. "Immiserizing growth." The New Palgrave (London: Macmillan, 1986c).

Bhagwati, Jagdish N., "New Economic Policy: Plea for faster domestic liberalization," Interview by $\mathrm{P}$. K. Roy in The Economic Times (16 September 1986d).

Bhagwati, Jagdish N., "Indian economic performance and policy design," 7th Sir Purshotam Thakurdar Memorial Lecture (Bombay: Indian Institute of Bankers, 21 December 1987); to be published 1988.

Bhagwati, Jagdish N., Richard Brecher, and Tatsuo Hatta, "The generalized theory of transfers and welfare: Bilateral transfers in a multilateral world," American Economic Review, Vol. 73, No. 4 (September 1984).

Bhagwati, Jagdish N., and T. N. Srinivasan. "Indian growth strategy: Some comments," Economic and Political Weekly (December 1984).

Bhalla, Surjit S.. "Is Sri Lanka an exception: A comparative study of living standards," in T. N. Srinivasan and Pranab Bardhan (Eds.), Rural Poverty in South Asia (New York: Columbia University Press, 1985a).

Bhalla, Surjit S., "Sri Lankan achievements: Facts and fancy," in T. N. Srinivasan and Pranab Bardhan (Eds.), Rural Poverty in South Asia (New York: Columbia University Press, 1985b).

Bhalla, Surjit S., and Paul Glewwe, "Living standards in Sri Lanka in the seventies: Mirage and reality" (Washington, DC: World Bank Development Research Department, 1985).

Bhalla, Surjit S., and Paul Glewwe, "Growth and equity in developing countries: A reinterpretation of the Sri Lankan experience," World Bank Economic Review, Vol. 1, No. 1 (September 1986).

Bhalla, Surjit S., and P. Vashistha, "Income distribution in India - A re-examination," in T. N. Srinivasan and Pranab Bardhan (Eds.), Rural Poverty in South Asia (New York: Columbia University Press. 1985).
Chenery, Hollis B.. Montek S. Ahluwalia, C. L. G. Bell. John Duloy and Richard Jolly. Redistribution with Growth (London: Oxford University Press. 1974).

Correa. H.. 1970, "Sources of economic growth in Latin America," Southern Economic Journal. Vol. 37 (1970).

Dandekar, V. M., and N. Rath, Poverly in India (Bombay: Indian School of Political Economy. 1971).

Dantwala, M. L.. "From stagnation to growth," Indian Economic Journal. Vol. 28. No. 2 (1970).

Deolalikar. Anil B., "Does nutrition determine labor productivity in agriculture? Wage equation and farm production function estimates for rural South India." Review of Economics and Statistics, Vol. 70. No. 2 (May 1988)

Desai. Padma. "China and India: Development during the last 25 years." The American Economic Review. Vol. 65, No. 2 (1975).

Dhar. P. N.. "Indian economy: Past performance and current issues." Paper presented to the Conference on the Indian Economy. Boston University. Boston. MA (1986).

Dhar. P. N.. "The political economy of development in India." Indian Economic Review, Vol. 32. No. 1 (1987).

Etienne, Gilbert. India's Changing Rural Scene. 19631979 (Oxford: Oxford University Press. 1982).

Glewwe. Paul, and Surjit S. Bhalla, "A response to comments by Graham Pyatt and Paul Isenman," World Bank Economic Review, Vol. 1, No. 3 (1987).

Hicks. Norman. "Economic growth and human resources," World Bank Staff Working Paper, No. 408 (Washington. DC: World Bank, 1980).

Hill, Polly, "The poor quality of official socio-economic statistics relating to the rural tropical world: With special reference to South India," Modern Asian Studies. Vol. 18, No. 3 (1984).

Hirway, Indira, Abolition of Poverty in India (New Delhi: Vikas, 1986a).

Hirway. Indira. Wage Employment Programmes in Rural Development (New Delhi: Oxford and IBH Publishing House, 1986b).

Isenman, P., "Basic needs: The case of Sri Lanka," World Development. Vol. 8, No. 3 (1980).

Isenman, P., "A comment on 'Growth and equity in developing countries: A reinterpretation of the Sri Lankan experience' by Bhalla and Glewwe." World Bank Economic Review. Vol. 1. No. 3 (1987).

Johnson, Harry G., "Economic expansion and international trade," The Manchester School, Vol. 23 (May 1955).

Joshi. Vijay, and I. M. D. Little, "Indian macroeconomic policies," Mimeo (Oxford: Nuffield College. Oxford University, 1986).

Kakwani, Nanak, "Is sex bias significant?" World Institute for Development Economics Research (Helsinki: December 1986).

Kohli, Atul, "Politics of economic liberalization in India," Mimeo (Princeton: Department of Political Science, Princeton University, 1987).

Kreuger, Anne O., Trade and Employment in Developing Countries: Synthesis and Conclusions, NBER 
(Chicago: Chicago University Press, 1983).

Lakdawala, D. T.. "Planning for minimum needs." Indulal Yagnik Memorial Lecture; in T. N. Srinivasan and Pranab Bardhan (Eds.), Rural Poverty in South Asia (New York: Columbia University Press. 1986), Chap. 12

Marris, Robin, "Economic growth in cross section: Ex+ periments with real product data. social indicators, model selection procedures, and policy benefit/cost analysis," Mimeo (Washington, DC: World Bank, 1982).

Mathur, Subodh C., "Rural poverty and agricultural performance in India: A comment," Journal of Development Studies (1985).

Minhas. Bagicha S., "Rural poverty, land distribution and development strategy," Indian Economic Review, Vol. 5, New Series (1970), pp. 97-126.

Minhas, Bagicha S., "Rural poverty and minimal level of living: A reply," Indian Economic Review, Vol. 6 , New Series (1971), pp. 69-77.

Minhas, B. S., L. R. Jain, S. M. Kansal, and M. R. Saluja, "On the appropriate choice of consumer price indices and data sets for estimating the incidence of poverty in India," Indian Economic Review, Vol. 22, No. 1 (1987).

Myrdal, Jan, Report from a Chinese Village (Signet Books Edition, 1966).

Nurkse, Ragnar, Patterns of Trade and Development, Wicksell Lectures (Stockholm: Almquist and Wick. sell, 1959).

Patel, I. G., "On taking India into the twenty-first century (New Economic Policy in India)," Kingsley Martin Memorial Lecture, Modern Asian Studies, Vol. 21. No. 2 (1986).

Pyatt, Graham, "A comment on "Growth and equity in developing countries: A reinterpretation of the Sri Lankan experience' by Bhalla and Glewwe." World Bank Economic Review, Vol. 1, No. 3 (1987).

Rath, N., "Garibi Hatao," Economic and Political Weekly (9 February 1985).

Rosenzweig, Mark, and Paul Schultz, "Market opportunities, genetic endowments and intra-family resource distribution: Child survival in rural India," American Economic Review, Vol. 72, No. 4 (September 1982).

Saith, A., "Production, poverty and prices in rural India," Journal of Development Studies, Vol. 17 (1981).

Sen, A. K., "Public action and the quality of life in developing countries," Oxford Bulletin of Economics and Statistics (November 1981).

Sen, A. K., "Family and food: Sex bias in poverty," in Resources, Values and Development (Oxford: Basil Blackwell, 1984).

Srinivasan, T. N., "Trends in agriculture in India: 1949-50 to 1977-78," Economic and Political
Weekly, Vol. $15(30,31,32$, Special Number, August 1979).

Srinivasan. T. N., "Was agriculture neglected in planning." Paper presented to the Golden Jubilee Seminar of the Indian Statistical Institute (Catcutta: December 1981); revised March 1982.

Srinivasan. T. N.. “Agricultural production, relative prices, entitlements and poverty," in John Mellor and Gunvant Desai (Eds.). Agricultural Change and Rural Poverty: Variations on a Theme by Dharam Narain (Baltimore, MD: Johns Hopkins University Press 1985).

Streeten, Paul, First Things First: Meeting the Basic Human Needs in Developing Countries (Oxford: Oxford University Press, 1981).

Subbarao, K.. "Regional variations in impact of antipoverty programmes: A review of evidence," Economic and Political Weekly, Vol. 20, No. 43 (26 October 1985).

Subbarao. K.. -Interventions to fulfill nutrition gaps at the household level: A review of India's experience," Paper prepared for a Workshop on Poverty in India, Queen Elizabeth House, Oxford University (1987).

Sundaram. K.. "Education, class structure and income inequality: Further evidence," World Development, Vol. 1. No. 6 (1973).

Sundaram, K.. "Growth, inequality and poverty: The Indian experience" (New Delhi: Centre for Policy Research. Chanakyapuri, 1986).

Sundaram, K., and S. D. Tendulkar, "Poverty reduction and redistribution in Sixth Plan: Population factor and rural-urban equity," Economic and Political Weekly, Vol. 18, No. 38 (17 September 1983a).

Sundaram. K., and S. D. Tendulkar, "Poverty in the mid-term appraisal," Economic and Political Weekly, Vol. 18 (5-12 November 1983b).

Sundaram. K., and S. D. Tendulkar, "Towards an explanation of inter-regional variations in poverty and unemployment in rural India," in T. N. Srinivasan and Pranab Bardhan (Eds.), Rural Poverty in South Asia (New York: Columbia University Press, 1983c).

Sundaram. K., and S. D. Tendulkar, "Integrated rural development programme in India: A case study of a poverty eradication programme," in S. Mukhopadhyay (Ed.), Case Studies on Poverty Programmes in Asia (Kuala Lumpur, Malaysia: APDC, 1985).

Tendulkar, Suresh D., "Rural institutional credit and rural development: A review article," Indian Econo. mic Review, Vol. 18, No. 1 (1983).

Weiner, Myron, "The political economy of growth in India," World Politics, Vol. 38, No. 4 (1986).

Wheeler, David, "Human resource development and economic growth in developing countries: A simultaneous Model," World Bank Staff Working Paper, No. 407 (Washington, DC: World Bank, July 1980). 